$\xi=-1$ 国

\title{
Modern Trends of Development of Industrial Tourism for Russian Universities
}

\author{
Krovopuskov P., Kantaryuk E., Chernyshova M. \\ Lipetsk State Technical University
}

\begin{abstract}
The paper deals with the coastal tourism in Iran and the United Arab Emirates by identifying the impact of tourist attractions on the development of coastal tourism in both countries, and the role of coastal tourism (beach, landscape, etc.) in attracting tourists in the two countries. In the present study, we investigated the environmental-ecological, socio-cultural, historical-political, economic, institutionalmanagerial and physical-spatial dimensions of the study area. The topicality of this work is the industrial tourism development. It will allow to enhance the economic potential of the regions, increase the flow of "domestic tourists» and improve the competitiveness of enterprises in the Region. It has been studied the prospects of industrial tourism development for students of universities in Russia and directly in the Lipetsk region at the present stage of development of the machine- and lathe-building industry.
\end{abstract}

Keywords: Tourist industry, modern development, University

\section{Introduction}

The pioneer of industrial tourism is USA. This type of tourism has been developing since the second half of the XIX century and today almost all enterprises are opened to tourists, because the closeness is a bad form and can damage the reputation of a company ultimately [1]. Industrial tourism is a quite interesting and exciting type of tourism. It should be taken into account that there is no any requirements for the special preparation or construction of a large number of facilities, so this type of tourism development is quite feasible. Russian infrastructure is not as well developed as in Western countries, but at the same time, there are impressive number of objects that could be included in industrial tourism in Russia, and all of them have a certain value [2]. Let us consider industrial tourism in Russia [3]. Its history goes back to the Soviet Union. Excursions to the confectionery factories were very popular in Moscow at that time. It is rather difficult to get to such events today. For a modern person, this kind of recreation is interesting, cognitive and allows him to see his city or some cultural and historical center from a different point of view. There are currently various tourist offices, which offer a wide range of sightseeing programs: visits to various farms, factories for the production of jewelry or Christmas toys, Khokhloma painting, pottery workshops, metallurgical and machine-tool enterprises and so on.

\section{Methodology}

Special attention should be paid to the agricultural sector in planning and policy making. Agricultural policy is the government intervention to organize the technical and social conditions of agricultural production, or the manifestation of any government political demand for agricultural transformation, while respecting the common power relations of society. As a result, with this interference, agricultural goals can be achieved by ordinary, financial and institutional means, and will adopt the arrangements, by dis- tributing the incomes from it, in order to increase agricultural productivity." Fundamental policies refer to policy sets, which lead to the improvement of the agricultural production structure and utilization system and provide the necessary infrastructure for agricultural development. The Tourism Industry Council was approved in Russia in the beginning of October 2017. According to the words of the Chairman of the Committee of the Chamber of Commerce and Industry of Russia on entrepreneurship in the sphere of tourist, resort and recreational and hotel activities - Yuri Barzykin, one of the tasks of the Council is to develop the uniform federal map of the special facilities that everyone can visit. [4]. Regions have begun to develop their routes. The newspaper "Arguments and Facts" reported that there is already a conglomerate of factories and factories open for tourists (fig. 1) [5]. Industrial tourism is one of the mechanisms that is necessary for the tourism development in general, as traditional varieties of tourism gradually lose its popularity in connection with people's striving for new discoveries, impressions and sensations [5].

\section{Results}

Let us look at the industrial tourism of students and lecturers of the Lipetsk State Technical University. It would be more correct to use the term "practice" in the educational process. There are various types of practices in each of the university's educational programs. They start with the training (introduction), the production and then finish with the pre-diploma. In accordance with the direction of education, a student begins visiting a profile enterprise that is engaged in this type of work or services. In accordance with the schedule of the educational process, students of all directions of the educational program of the Institute of Mechanical Engineering LSTU have practice at various enterprises of the Lipetsk region and other regions of the Russian Federation annually. Most 
of enterprises belong to the machine-building and lathe-building cluster.

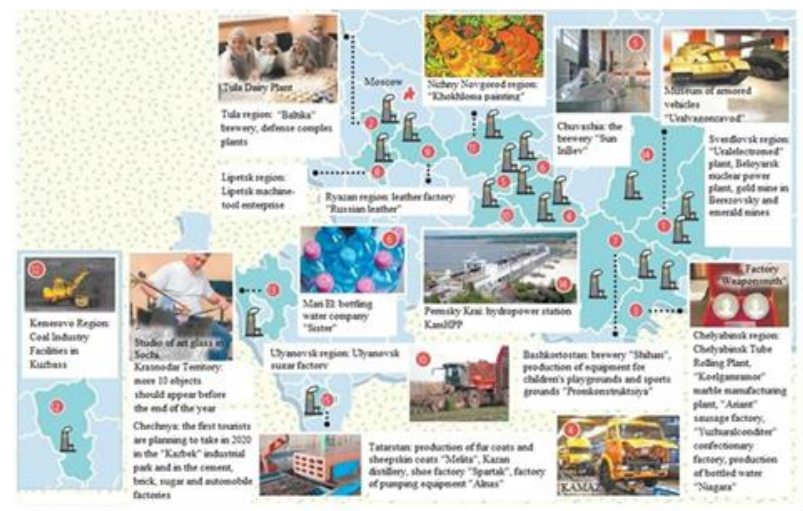

Fig.1. RF production enterprises which open to the visitors

Figure 1. The effect of truism in development

This type of tourism can be carried out in the framework of scientific events, patriotic educational projects, etc. Like for example, a forum "Metallurgy-Mechanical Engineering", organized within the Inter-University Patriotic Educational Project "RUSSIA. FUTURE. I'M PROUD! Professions." was held in the University on the 25th of April 2017. Another event, the excursion to the Lebedyansky Machine Building Plant was organized for 30 students of the Institute of Mechanical Engineering, headed by lecturers on April 26. Within the framework of the scientific conference "Actual issues of the machine tool industry development", which was held on the basis of the Machine-Building Institute of the LSTU, a visit to the machine-tool cluster "LIPETSKMASH" took place on November 30.

\section{Conclusion}

Tourism is a multi-purpose activity that takes place outside the normal tourist environment, and the travel of a tourist lasts more than a year for the purpose of recreation, commerce or other activities .If coastal areas and marine environments are to be considered for such activities, they will be called coastal tourism. Coastal tourism involves traveling from a place of residence and focusing on marine environments. The concept of coastal tourism encompasses a full range of tourism, leisure and recreational activities occurring in coastal areas and near coastal waters. Mobility of students and lecturers should be organized not only in the educational process, but also in other formats. This fact is aimed at improving the qualifications of the lecturers themselves and partial formation of ideas about their chosen profession among the students, due to the introduction of advanced technologies in production, the latest equipment, both foreign and domestic. This is a good opportunity for students, because during the training they can not only theoretically, but also practically apply the acquired knowledge and skills in real production and plunge into the world of technological novelties. This is the prerequisite for the formation of an incorruptible interest among graduates to a future profession.

\section{References}

[1] Sklyarenko S.A, (2011), Perspectives of the industrial tourism development in Russia, S.A. Sklyarenko, T.M. Panchenko, I.A. Selivanov and others, Russian Entrepreneurship, No. 10 (1), pp. $146-$ 150 .
[2] Brovkina M, (2017), Plant in the collection [Electronic resource], M. Brovkina, Rossiyskaya Gazeta - The Economy of the South of Russia, No. 7406 (240), Access mode: https://rg.ru/2017/10/24/regufo/kak-na-iuge-rossii-razvivaetsia-promyshlennyj-turizm.html (Last accessed date 13/05/2018).

[3] Industrial tourism in Russia. Infographics [Electronic resource], Arguments and Facts, (2017), № 42. Access mode: http://www.aif.ru/dontknows/infographics/promyshlennyy_turizm _ v rossii infografika (Last accessed date 13/05/2018).

[4] Tonkovid S.B, (2016), Import substitution of foreign industrial products by improving the formation of domestic analogues, Tonkovid S. B., Korneev A. M., Chilikin A. N. and others., Design. Materials. Technologies, T.2, No. 42, pp. 53-55.

[5] Dmitriev AA, Industrial tourism: modern development trends. AUTOABSTRACT OF THE BAKALAVRE DIPLOMATIC WORK [Electronic resource] URL: http://elibrary.sgu.ru/VKR/2016/43-0302_030.PDF (Last accessed date 13/05/2018). 